\title{
ПЕРСПЕКТИВЫ НЕФТЕГАЗОНОСНОСТИ ТРИАСОВЫХ ОТЛОЖЕНИЙ ПРИКАСПИЙСКОЙ ВПАДИНЫ
}

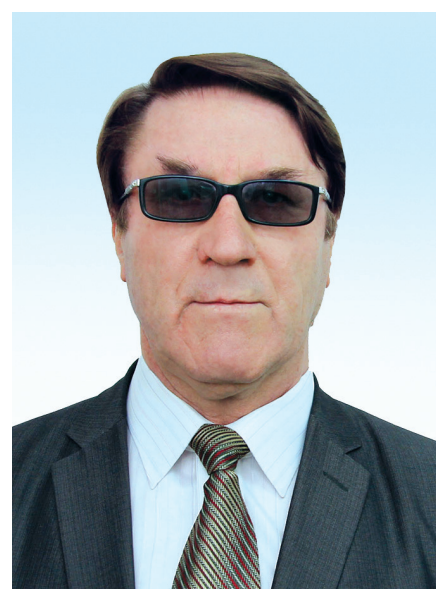

Г.В. ВОРОНОВ',

главный геофизик, https://orcid.org/0000-00024189-9847

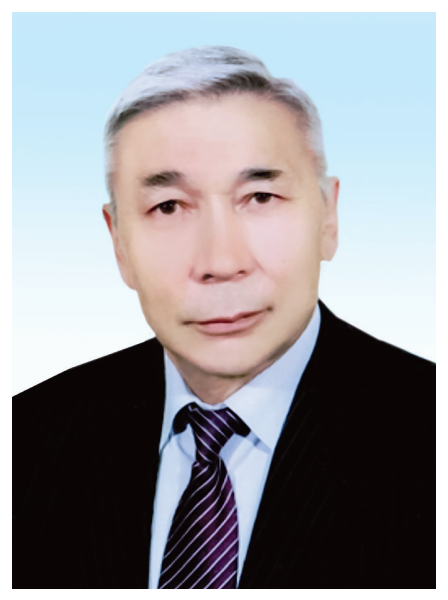

H.E. KУAHTAEB',

кандидат геол.-мин. наук, академик Академии минеральных ресурсов РК, директор алматинского фрилиала КОНГ, https://orcid.org/ 0000-00017159-2005

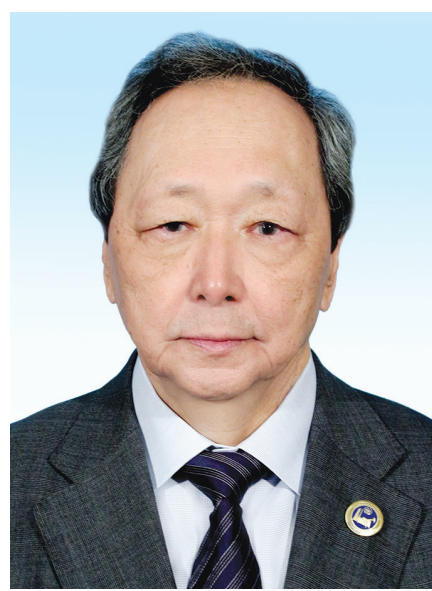

Б.А. ЕСКОЖА ${ }^{3 *}$, кандидат геол.-мин. наук, председатель правления

TOO «AralMunaiGas», https://orcid.org/0000-00029069-897X

'ТОО «МЕРИДИАН-ЕВРАЗИЯ»,

Республика Казахстан, 050040, г. Алматы, ул. Байзакова, 280

²АЛМАТИНСКИЙ ФИЛИАЛ КАЗАХСТАНСКОГО ОБЩЕСТВА НЕФТЯНИКОВ-ГЕОЛОГОВ Республика Казахстан,050020, г. Алматы, ул. Байкадамова, 2Б

${ }^{3} \mathrm{TOO}$ «ARALMUNAIGAS»,

Республика Казахстан, 050040, г. Алматы, ул. Байзакова, 280

Осуществлен анализ результатов геологоразведочных работ последних лет на триасовый комплекс и дан прогноз перспектив нефтегазоносности отложений триаса в Прикаспийской впадине. Исследования проведены с позиции объектно-ориентированного сейсмогеологического анализа к прогнозированию и картированию новых типов структур в этом комплексе, названных структурно-седиментационными ловушками. Выявление подобных ловушек стало возможным благодаря обработке сейсмических данных по специальной методике. Результатами бурения подтверждено наличие таких ловушек в среднем mриасе и их нефтегазоносность, что в конечном итоге вылилось в новое направление геологоразведочных работ на надсолевой комплекс отложений в Прикаспийской впадине, основанное на прогнозе структурно-седиментационных ловушек.Данная методика объектно-ориентированного сейсмогеологического анализа сейсмических данных реализована на территории Прикаспийской впадины в пределах Актюбинской и Атырауской областей Республики Казахстан. Анализ сейсмических данных позволил составить прогнозную карту

\footnotetext{
* Адрес для переписки. E-mail: b.yeskozha@gmail.com
} 
распространения ловушек нового типа и дать рекомендации по направлениям работ на триасовый комплекс в Прикаспийской впадине.

КЛЮЧЕВЫЕ СЛОВА: Прикаспийская впадина, триасовый комплекс, объектно-ориентированная обработка, структурно-седиментационные ловушки, критерии прогноза, нефтегазоносность.

\section{КАСПИЙ МАҢЫ ОЙПАТЫНЫҢ ТРИАС ШӨГІНДІЛЕРІНІҢ МҰНАЙ-ГАЗ ПЕРСПЕКТИВАЛАРЫ}

Г. В. ВОРОНОВ 1 , бас геофизигі, https://orcid.org/ 0000-0002-4189-9847

H.Е. ҚУАНТАЕВ², геология-минералогия ғылымдарының кандидаты, ҚР Минералдық ресурстар академиясының академигі, Мұнайшы-Геологтардың Қазақстандық Қоғамы Алматы срилиалының директоры, https://orcid.org/0000-0001-7159-2005

Б.А. ЕСкОжА ${ }^{3}$, геология-минералогия ғылымдарының кандидаты, ҚР Минералдық ресурстар академиясының академигі, Мұнайшы-Геологтардың Қазақстандық Қоғамы Алматы фрилиалының директоры, https://orcid.org/0000-0002-9069-897X

${ }^{1}$ «МРИДИАН-ЕВРАЗИЯ» ЖШС,

Қазақстан Республикасы, 050040, Алматы қ., Байзақов к-сі, 280

²ҚАЗАҚСТАНДЫҚ МҰНАЙШЫ-ГЕОЛОГТАР ҚОҒАМЫНЫҢ АЛМАТЫ ФИЛИАЛЫ, Қазақстан Республикасы, 050020, Алматы қ., Байқадамов к-сі, 26

${ }^{3}$ «ARALMUNAIGAS» $Ж Ш \mathrm{C}$

Қазақстан Республикасы, 050040, Алматы қ., Байзақов к-сі, 280

Соңғы жылдары триас кешенінде жүргізілген геологиялық барлау жұмыстарының нәтижелеріне талдау жасалып, Каспий маңы ойпатындағы Триас шөгінділерінің мұнай-газ әлеуетінің болашағы болжалды.Зерттеулер объектілік-сейсмикалық-геологиялық талдау позициясынан бастап құрылымдағы-тұндырғыш тұзақтар деп аталатын құрылымның жаңа типтерін болжау мен картаға түсіруге дейін жүргізілді.Мұндай тұзақтарды анықтау сейсмикалық мәліметтерді арнайы техниканың көмегімен өңдеудің арқасында мүмкін болды. Бұрғылау нәтижелері мұндай траптардың орта триаста бар екендігін және олардың мұнай-газ әлеуетін растады, нәтижесінде құрылымдық-седиментациялық тұзақтардың болжамына сүйене отырып, Каспий бассейніндегі тұздан кейінгі кен орындарында барлау жұмыстарының жаңа бағыты пайда болды. Сейсмикалық деректерді нысанға бағытталған сейсмикалық талдаудың бұл әдісі Қазақстан Республикасының Ақтөбе және Атырау облыстары шедінде орналасқан Каспий маңы ойпаты аумағында жүзеге асырылды. Сейсмикалық деректерді талдау жаңа типтегі тұзақтардың таралуының болжамды картасын құруға және осы Каспий маңы ойпатының триастық кешендегі жұмыс бағыттары бойынша ұсыныстар беруге мүмкіндік берді.

ТҮЙІн СөзДЕР: Каспий маңындағы ойпат, триас кешені, объектіге бағытталған өңдеу, құрылымдық тұнбаға түсіру тұзақтары, болжамдық өлшемшарттары, мұнай-газ әлеуеті.

\section{PROSPECTS FOR THE OIL AND GAS POTENTIAL OF THE TRIASSIC DEPOSITS OF THE PERI-CASPIAN DEPRESSION}

G.V. VORONOV ${ }^{1}$, Chief Geophysicist, https://orcid.org/0000-0002- 4189-9847

N.E. KUANTAYEV ${ }^{2}$, candidate of geological and mineralogical sciences, Academician of the Academy of Mineral Resources of Kazakhstan, Director of the Almaty Branch of the Kazakhstan Association of Petroleum Geologists, https://orcid.org/ 0000-0001-7159-2005 
B.A. YESKOZHA ${ }^{3}$, candidate of geological and mineralogical sciences, mining engineer-geologist, chairman of the board of AralMunaiGas LLP, https://orcid.org/0000-0002-9069-897X

${ }^{1}$ MERIDIAN-EURASIA LLP,

Republic of Kazakhstan, 050040, Almaty, Baizakov Street 280

${ }^{2}$ ALMATY BRANCH OF THE KAZAKHSTAN ASSOCIATION OF PETROLEUM GEOLOGISTS, Republic of Kazakhstan, 050020, Almaty, Baikadamov Street, 2-B

${ }^{3}$ ARALMUNAIGAS LLP,

Republic of Kazakhstan, 050040, Almaty, Baizakov street, 280

An analysis of the results of geological exploration work in recent years for the Triassic complex is carried out and a forecast of the prospects for the oil and gas potential of the Triassic sediments in the Caspian Basin is given. The studies were carried out from the position of object-oriented seismic-geological analysis to forecasting and mapping new types of structures in this complex, called structural-sedimentation traps. The identification of such traps became possible due to the processing of seismic data using a special technique. The drilling results confirmed the presence of such traps in the Middle Triassic and their oil and gas potential, which ultimately resulted in a new direction of exploration work on the post-salt complex of deposits in the Caspian basin, based on the forecast of structural-sedimentation traps. This method of object-oriented seismic-geological analysis of seismic data has been implemented on the territory of the Caspian Basin within the Aktobe and Atyrau regions of the Republic of Kazakhstan. Analysis of seismic data made it possible to compile a predictive map of the distribution of traps of a new type and give recommendations on the directions of work on this Triassic complex in the Caspian Basin.

KEY WORDS: Precaspian basin, Triassic sequence, target-oriented processing, structuredsedimentation traps, forecast criteria, oil and gas bearing potential.

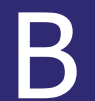

пределах Прикаспийской впадины нефтегазоносность установлена как в подсолевом палеозое, так и в надсолевом мегакомплексе отложений. Хотя верхнепермская и триасовая толщи характеризуются аномально увеличенной толщиной осадков (порядка 3600 и 2500 м соответственно) и спорадической нефтегазоносностью, основной объем нефти традиционно добывается из отложений юры и мела. Как показывает практика геологоразведочных работ на нефть и газ в Прикаспийской впадине, в силу изученности региона геолого- геофизическими методами разведки, фонд легко осваиваемых структур в юрско-меловом комплексе отложений практически уже исчерпан. Работающие на нефтегазовых месторождениях надсолевого комплекса нефтяные компании в основном используют запасы нефти и газа, выявленные еще в советский период. Восполнение нефтегазовых запасов в надсолевых отложениях возможно только при открытии новых залежей углеводородов в нетрадиционных геологических объектах и комплексах. Одним из таких слабо изученных комплексов, где прогнозируются перспективные геологические объекты с доказанной нефтегазоносностью, являются триасовые отложения Прикаспийской впадины.

Триасовые и верхнепермские отложения чрезвычайно близки в литолого-фациальном отношении, поскольку палеогеографическая обстановка в начале триасового периода была в значительной степени унаследована от позднепермского времени. Такое сходство создавало определенные трудности и долгое время они выделялись как единая толща под названием «пермотриас».

Изучением проблемы стратиграфии и литологии пермотриаса занимались многие исследователи и ими были разработаны местные литолого-стратиграфические схемы 
для отдельных структурно-фациальных зон. По региональной стратиграфической схеме триаса Прикаспийской впадины, разработанной Е.И. Соколовой в 1958 году, выделены нижний отдел в составе ветлужской и баскунчакской серий и верхний отдел. Однако ввиду неравнозначности исходных палеонтологических определений приводило это к формальным сопоставлениям разрезов без достаточного обоснования выделяемых стратиграфических подразделений.

Дальнейшими усилиями ученых Ф.Ю. Киселевского, Н.Н. Старожиловой, А.Ю. Лопато, Л.Я. Сайдаковского, Е.В. Мовшовича, В.И. Левиной, Д.А. Кухтинова, В.В. Липатовой, А.Г. Шлейфер, М.И. Богачевой, Б.А. Ескожа, Н.Е. Куантаева разработаны биостратиграфические схемы и определено развитие в Прикаспийской впадине всех трех отделов триаса. И здесь следует отметить значительный вклад геологов В.В. Липатовой и Н.Н. Старожиловой, выделивших средний триас в северной части Волго-Уральского междуречья и подтвердивших предположение В.В. Мокринского о наличии среднетриасовых отложений в районе оз. Индер. По этим материалам средний триас включает терригенно-карбонатную часть разреза, заключенного между красноцветной и преимущественно сероцветной континентальными толщами нижнего и верхнего триаса, которая ранее принималась за баскунчакскую серию нижнего триаса.

Следует отметить, что при решении сложной проблемы триаса были комплексно учтены цикличность осадконакопления, палеогеографическая, палеогидрогеологическая и палеотектоническая обстановки развития региона.

В целом, осадочный цикл триаса Прикаспийской депрессии начинается трансгрессивным комплексом красноцветных континентальных терригенных образований, затем сменяется морскими преимущественно сероцветными терригенно- карбонатными и заканчивается регрессивным комплексом терригенных континентальных образований, накопленных в условиях гумидного климата. Эти седиментационные циклы соответствуют трем отделам триасовой системы.

По структурно-стратиграфическим особенностям стало возможным выделить принципиально отличающиеся купольный, мульдовый и «подкарнизный» типы толщ разреза триаса.

Выявленные особенности строения триаса положительно сказались на результатах дальнейших геологоразведочных работ и дали импульс к более осознанному и целенаправленному изучению перспективной толщи триаса [1-3]. Отправной точкой стало открытие крупного нефтяного месторождения Кенбай, где участок Котыртас Северный характеризуется наличием 7-ми горизонтов в среднем триасе и месторождения Сайгак где в континентальных отложениях нижнего триаса и верхней перми установлено 10 пластово-линзовых залежей нефти общей мощностью 24-62 м. [4-8]. Эти открытия резко повысили интерес к изучению надсолевых отложений и вызвали поток публикаций, где приводились модели развития процессов галокинеза, схемы формирования межкупольных зон и различные типы вероятных ловушек для оценки потенциальных ресурсов надсолевого комплекса [9-13]. Наиболее полно попытка определения природы формирования структурно-седиментационных и других типов периферийных ловушек сделана М.С. Трохименко [14,15]. Однако ряд допущений и противоречий имеющихся как в этой работе, так и у других исследователей [12-16], относительно природы образования и роста структур в триасе в силу их слабой изученности, недоучет регионального перерыва между триасом и юрой 
и другие особенности геологического строения не позволяют признать эти модели как обоснованную прогнозную геологическую модель формирования нефтегазовых месторождений в триасовом комплексе, что ставит под сомнение выводы авторов и не дает возможности успешно применять их на практике.

Технологический прогресс и развитие сейсморазведки значительно улучшили качество получаемых сейсморазведочных данных, что позволило более глубже заглянуть в эту толщу и выявлять перспективные объекты в них. Однако, несмотря на установленную нефтегазоносность, вопросы геологического строения, определение возраста, установление природы и типов ловушек, критериев их выделения изучены еще весьма слабо. Проблемы заключаются в стратификации триасовых отложений, заключенных в глубоких межкупольных мульдах ввиду малочисленности данных глубокого бурения вне сводов соляных куполов. Поэтому однозначная идентифиция полученных отражений по данным сейсморазведки в отдельно взятой межкупольной зоне и тем более в различных мульдах, вызывает серьезные трудности.

Располагая многолетним практическим опытом работы в солянокупольной области, нами были проведены целенаправленные исследования и анализ всех ранее проведенных работ для разработки технологии прогнозирования и картирования перспективных геологических объектов и ловушек в отложениях триаса, благоприятных для скопления нефти и газа.

Решение проблемы заняло несколько этапов.

На начальном этапе проводился сбор, систематизация, анализ и обобщение значительного объема полученной в предыдущие годы геолого-геофизической информации. Для всей территории была выполнена комплексная интерпретация гравиметрических данных совместно с материалами имеющейся сейсморазведки и данных бурения [17]. На полученных структурных картах кровли соленосных отложений были выделены крутые склоны соляных ядер куполов, предполагаемые соляные «карнизы» и бессолевые межкупольные депрессии. Это было необходимо сделать для выбора наиболее значимых факторов для районирования территории с целью предварительной оценки перспективности отдельных групп соляных куполов и ориентировочного выявления потенциальных объектов для проведения дальнейших геолого-геофизических исследований, а также анализа истории развития купола или мульды для оценки перспективности возможных ловушек в надсолевом комплексе.

Относительно вопросов влияния истории развития купола или мульды на продуктивность локальных структурных образований мнение исследователей едино: длительно развивающиеся и наиболее «зрелые» межкупольные мульды имеют более высокие перспективы нефтегазоносности, чем мульды, начавшие свое формирование в более поздние этапы галокинеза. Для соляных куполов эта зависимость обратная. Наиболее зрелые купола (открытопрорванные) обладают меньшими перспективами, чем купола, формирование которых находится на более поздних стадиях (скрытопрорванные и глубокопогруженные).

Кроме того, не исключается возможность вертикальной миграции УВ из докунгурских подсолевых отложений, главным образом, в районе сквозных бессолевых мульд. Депоцентрами надсолевого нефтегазообразования являются мульды, и прежде всего их центральные части, где потенциальные нефтегазоматеринские отложения 
попали в оптимальные для генерации УВ термобарические условия. Синклинальная форма межкупольных мульд, неравномерное распределение давления, максимального в их центральной части и убывающего к периферии, наличие ловушек в бортовых зонах, сформировавшихся еще в ходе осадконакопления, - все это создает предпосылки для начала движения первоначально рассеянной нефти и газа вверх по региональному восстанию пластов - от центральной части бассейна к его периферии и формированию залежей в ловушках на пути миграции нефти и газа. По своему строению межкупольные мульды характеризуются всесторонним экранированием заключенных в них пластовых резервуаров обрамляющим барьером соляных гряд и куполов и образуют естественные трехмерные пространства для аккумуляции УВ. В аспекте нефтегазогеологического районирования каждая межкупольная мульда может рассматриваться, как в значительной степени, автономный седиментационный микробассейн. Если исключить фоновое для всех надсолевых мульд "УВ-дыхание" из подсолевых отложений, каждая мульда является нефтегазогенерирующей (при наличии нефтематеринских отложений) и аккумулирующей системой, динамично функционирующей в пространстве и времени. Наличие нефтяных и газовых скоплений в относительно замкнутой нефтегазовой системе определяется ее объемными параметрами, миграционно-дренажной характеристикой и способностью к аккумуляции УВ. Очевидно, что особенности развития этих систем и определяют дифференциацию межкупольных мульд по степени перспективности. Исходя из этого, стратегия выделения наиболее перспективных объектов для детального изучения определялась выявлением региональных и локальных путей миграции углеводородов в надсолевой верхнепермско-триасовой толще и проведением для каждой рассматриваемой мульды детального палеотектонического анализа.

На втором этапе осуществлены полевые сейсморазведочные работы МОГТ на выбранных объектах, обработка и интерпретация полученных данных сейсморазведки с подготовкой перспективных ловушек для постановки поисково-разведочного бурения.

Наблюдаемые на сводах соляных куполов и во многих мульдах структурные и стратиграфические соотношения выполняющих их напластований создают предпосылки для формирования ловушек тектонически экранированного, литологического и стратиграфического типов. Различные группы ловушек-резервуаров требуют определенной специфики как при подготовке локальных объектов, так и в процессе проведения поисково-разведочных работ. Поэтому был проведен тщательный анализ различных типов ловушек и для определения основного направления геологоразведочных работ выбраны периферийные структурно-седиментационные триасовые ловушки в «надкарнизном» залегании. Были целенаправленно проанализированы все имеющиеся материалы сейсморазведочных работ на предмет выявления и картирования подобных ловушек-резервуаров. Одним из первых практических подтверждений продуктивности подобных ловушек получено на примере месторождения Таскудук Западный, где установлена продуктивность отложений среднего триаса.

Выявленные месторождения нефти и газа в триасовых отложениях, связанных со структурно-седиментационными ловушками, имеют довольно сложное строение резервуара, что предопределяет новые требования к подготовке таких объектов, когда необходимо не только картировать структурную поверхность резервуара, но и определять 
зоны замещения и выклинивания перспективных пластов пород. Поэтому необходимо применение более детальной и объектно-ориентированной обработки сейсмических данных при изучении триасовых отложений и выявлению характерных геофизических признаков и критериев при выделении и прогнозировании новых объектов.

Общая направленность объектно-ориентированной обработки для получения временных разрезов ОГТ заключается в достижении максимально возможных соотношений сигнал/помеха и разрешенности сейсмической записи - выделение и прослеживание на временных разрезах особенностей волнового поля преимущественно в верхней части триасовых отложений, которые характеризуются меньшими соотношениями сигнал/помеха и являются сейсмическим отображением потенциально перспективных нефтегазосодержащих толщ. Отличительная особенность технологии специальной объектно-ориентированной обработки сейсморазведочных данных МОГТ - выбор оптимальных обрабатывающих процедур и их параметров, которые обеспечивают последовательное выделение и подчеркивание характеристик волнового поля, удовлетворяющих свойствам и типам совершенствующейся в процессе обработки конкретной геологической модели и предусматривает:

- адаптацию параметров обрабатывающих процедур к изменяющимся сейсмогеологическим условиям;

- использование различных фильтраций и нуль-фазовой деконволюции с настройкой фильтров по различным временным окнам в соответствии с изменяющимся во времени частотным спектром сейсмических колебаний, что позволяет получить максимально возможные разрешенность и динамическую выраженность сейсмической записи;

- DMO-преобразование (DEEP MOVE OUT CORRECTION) сейсмограмм OГT, служащее для устранения влияния наклонов и кривизны отражающих границ на скорость суммирования отраженных и рассеянных волн по сейсмограммам ОГТ;

- подавление (вычитание) кратных волн двухмерной фильтрацией на сейсмограммах ОГТ;

- многократную коррекцию кинематических и статических поправок по интервалам сейсмической записи (временным окнам), соответствующим отложениям триаса и вышележащим толщам отложений;

- «мягкую» коррекцию остаточных фазовых сдвигов;

- максимальное подавление (вычитание) среднескоростных волн-помех;

- коррекцию формы сейсмических сигналов с помощью фильтрации суммарных трасс временного разреза (Винера, фазовой деконволюции, фазовым фильтром);

- временную миграцию до суммирования во временной (глубинной) области.

Применение всех процедур позволило обеспечить приемлемую когерентность триасовых отражений с желательной величиной разрешенности.

В результате разработанной технологии объектно-ориентированной методики обработки данных сейсморазведки, на временных разрезах МОГТ получена информация об особенностях геологического строения изучаемых объектов:

- получены принципиально новые результаты по разделению сейсмической записи в интервале регистрации триасовых отложений с выделением отражений, соответствующих несогласным границам раздела в триасовой толще; 
- практически повсеместно стало возможным проследить отражающие горизонты, связанные с продуктивными пластами и их аналогами, приуроченным к среднему триасу;

- в различных сейсмофациях нашло отражение смена фациального состава пород;

- установлены закономерности в сочетании морфологических элементов структур, сейсмоморфологическом облике проявления триасовых объектов и их аномальном проявлении в полях сейсмических параметров;

- разработаны сейсмические критерии прогноза структурно-седиментационных ловушек.

Развитие сейсмических технологий и методики обработки сейсмических данных обеспечило возможность более детального изучения структурных планов непосредственно продуктивных пластов, выделение и трассирование малоамплитудных дизъюнктивных дислокаций, разрушающих сплошность природных резервуаров в среднетриасовом комплексе и разделяющих их на отдельные блоки.

Ранее проводимая стандартная обработка по всему разрезу без учета априорной информации о строении триасовых отложений в области размещения предполагаемых нефтеперспективных ловушек не приводила к их выделению и этот тип ловушек не был известен (рисунок 1). Общая линзовидная форма в разрезе и характерная форма сейсмической записи, сходная с дифрагированными волнами, создают сложную волновую картину. Поэтому при обработке и интерпретации сейсмических данных прошлых лет волновые аномалии, соответствующие этим телам, обычно игнорировались. Основной причиной таких ошибок является наблюдаемый на границе соляного купола и вмещающих карбонатно-глинистых пород “скачок” отражений, соответствующий появлению слоистых пачек глинистых пород, залегающих несогласно и воздымающихся к своду купола. Дополнительные проблемы в поиске данных ловушек связаны с тем, что структурные планы этих объектов не совпадают со структурными планами юрско-меловой и всей триасовой толщи в межкупольной зоне, ориентируясь на которые традиционно велись поиск и разведка в Прикаспийской впадине.

В результате реализованной технологии объектно-ориентированной методики обработки сейсморазведочных данных на временных разрезах ОГТ, разрезах сейсмических атрибутов выделены и практически повсеместно прослежены отражающие горизонты, связанные с продуктивными пластами и их аналоги, приуроченные к среднему триасу. Кроме того, в различных сейсмофациях нашла отражение смена фациального состава отложений. В основном это связано с увеличением детальности и информативности сейсмических разрезов за счет восстановления малоразмерных объектов с определенными геометрическими свойствами, на фоне регулярных отражающих границ (рисунок 2).

С учетом проведенной объектно-ориентированной обработки разработаны сейсмические критерии прогноза структурно-седиментационных ловушек, основанные на выделении на временных разрезах волновых аномалий, соответствующих триасовым структурно-седиментационным ловушкам. Данные поисковые объекты приурочены к периферийным участкам соляных куполов с крутым погружением соли и имеют форму крупной клиноформной линзы с различной степенью морфо- 


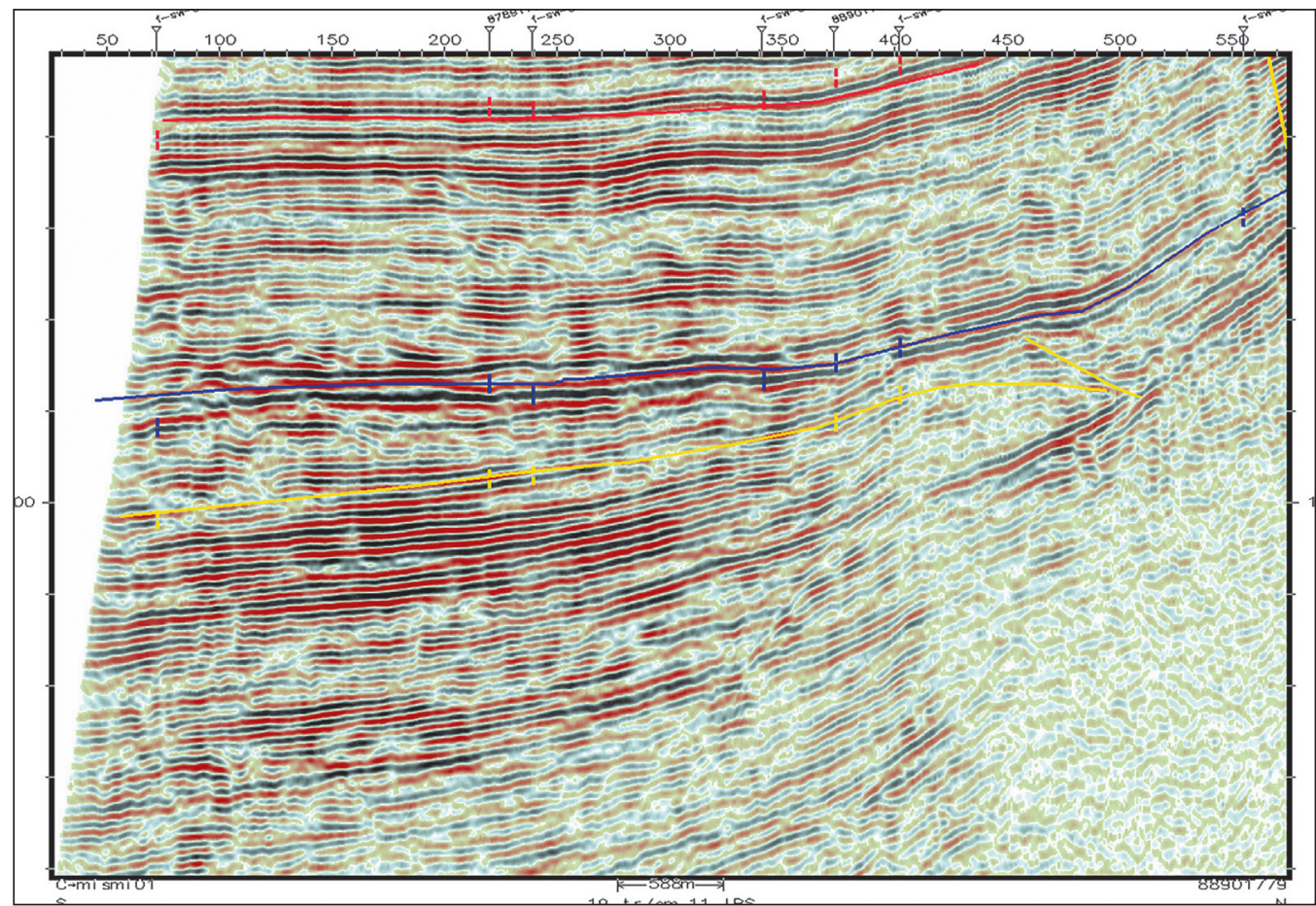

Рисунок 1 - Пример стандартной обработки на триасовую структуру

логической выраженности, а оптимизация методики объектно-ориентированной обработки данных сейсморазведки, исходя из априорной информации об особенностях геологического строения изучаемых объектов, позволила получить принципиально новые результаты по разделению сейсмической записи в интервале регистрации триасовых отложений с выделением отражений, соответствующих несогласным границам раздела в триасовой толще (рисунки 2, 3). Установлены закономерности в сочетании морфологических элементов структур, сейсмоморфологическом облике проявления триасовых объектов и их аномальном проявлении в полях сейсмических параметров на временных разрезах (рисунок 3). Основным сейсмическим критерием прогноза перспективных структурно-седиментационных ловушек служит выделение структурных несогласий связанных с палеоподнятием внутри триасовых отложений на границе с кунгурской солью. Также критерием перспективности выделенных структурно-седиментационных ловушек служит наличие стратиграфического несогласия между верхним купольным триасом и средним межкупольным триасом.

Следует подчеркнуть, что весь этот пакет результативных сейсмических материалов позволил получить принципиально новую геолого-геофизическую информацию о строении отложений среднего триаса и вся новая информация проэталонирована по данным бурения и ГИС при подсчете промышленных запасов, а потому является однозначно достоверной.

Описанные методика и технология обработки данных МОГТ могут быть применены на других площадях Прикаспийской впадины для получения уверенных 


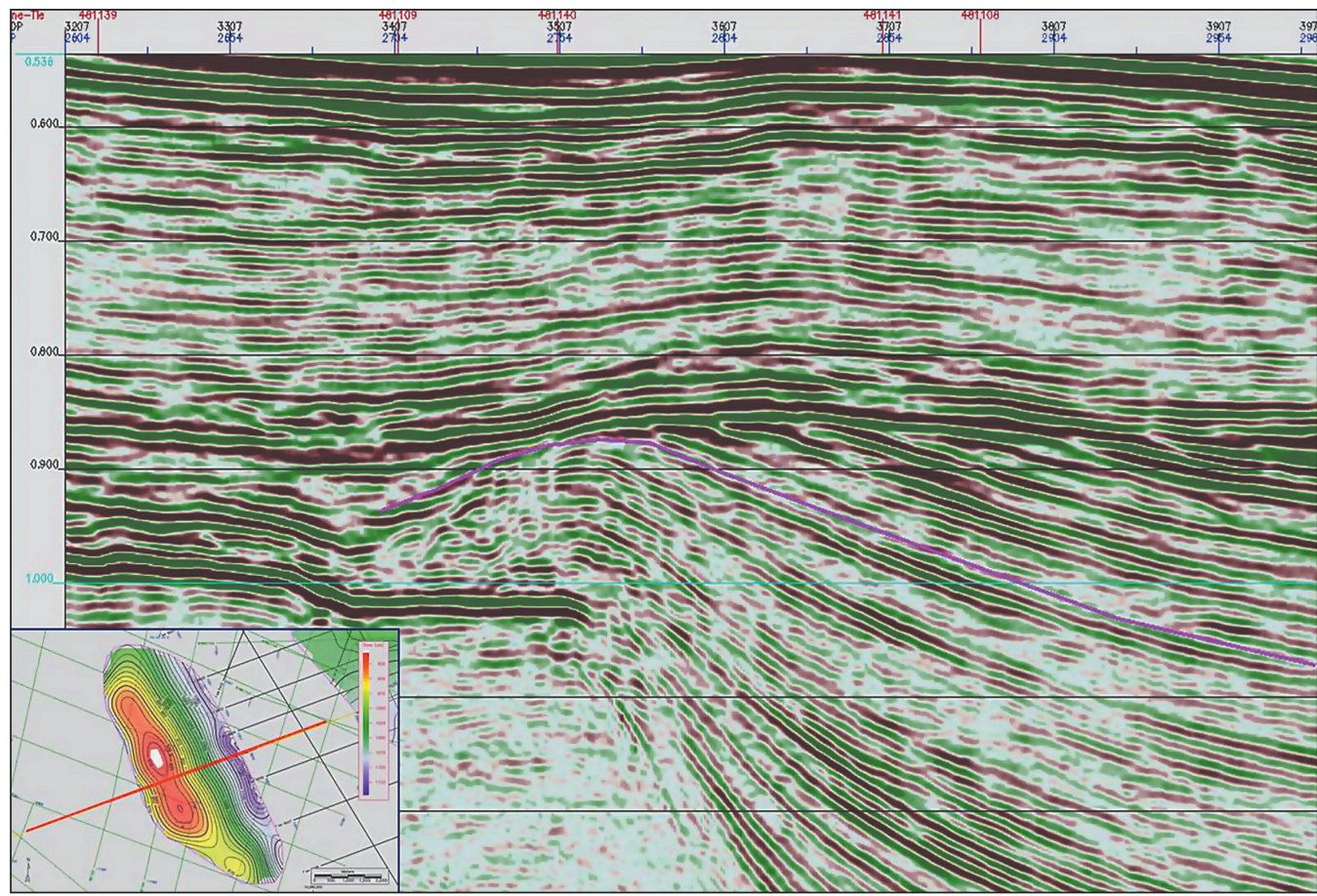

Рисунок 2 - Пример объектно-ориентированной обработки на триасовую структуру

данных по отложениям триаса, что позволит получить значительный геологический результат и экономический эффект.

Исходя из анализа сейсмических материалов и данных бурения были определены следущие критерии и признаки для выбора наиболее вероятных перспективных объектов нефтегазонакопления:

• в Прикаспийской впадине кунгурско-триасовый структурный этаж особенностями своего строения в значительной степени обязан проявлениям солянокупольной тектоники;

- все открытые нефтегазовые месторождения надсолевого триаса приурочены к периферийным участкам глубоких межкупольных мульд, в которых практически вся соль отжата в соляные купола и гряды, и не играет экранирующей роли для подсолевых отложений («соляные окна»);

- межгрядовые участки и мульды, обрамленные соляными грядами, включают в себя наиболее объемные по запасам нефти триасовые ловушки различного типа;

- ряд месторождений приурочен к соляным грядам и местам их пересечения сочленениям. В связи с этим надо полагать, что поступающие из глубинных отложений углеводороды мигрировали по региональному воздыманию и затем, как по одному из вероятных путей, вдоль соляных гряд, скапливались в структурных формах, связанных с соляными куполами, расположенных на путях миграции нефти и газа;

- особенно перспективными следует считать участки периферийных структурно-седиментационных триасовых ловушек, обращенных открытой (незамкнутой 


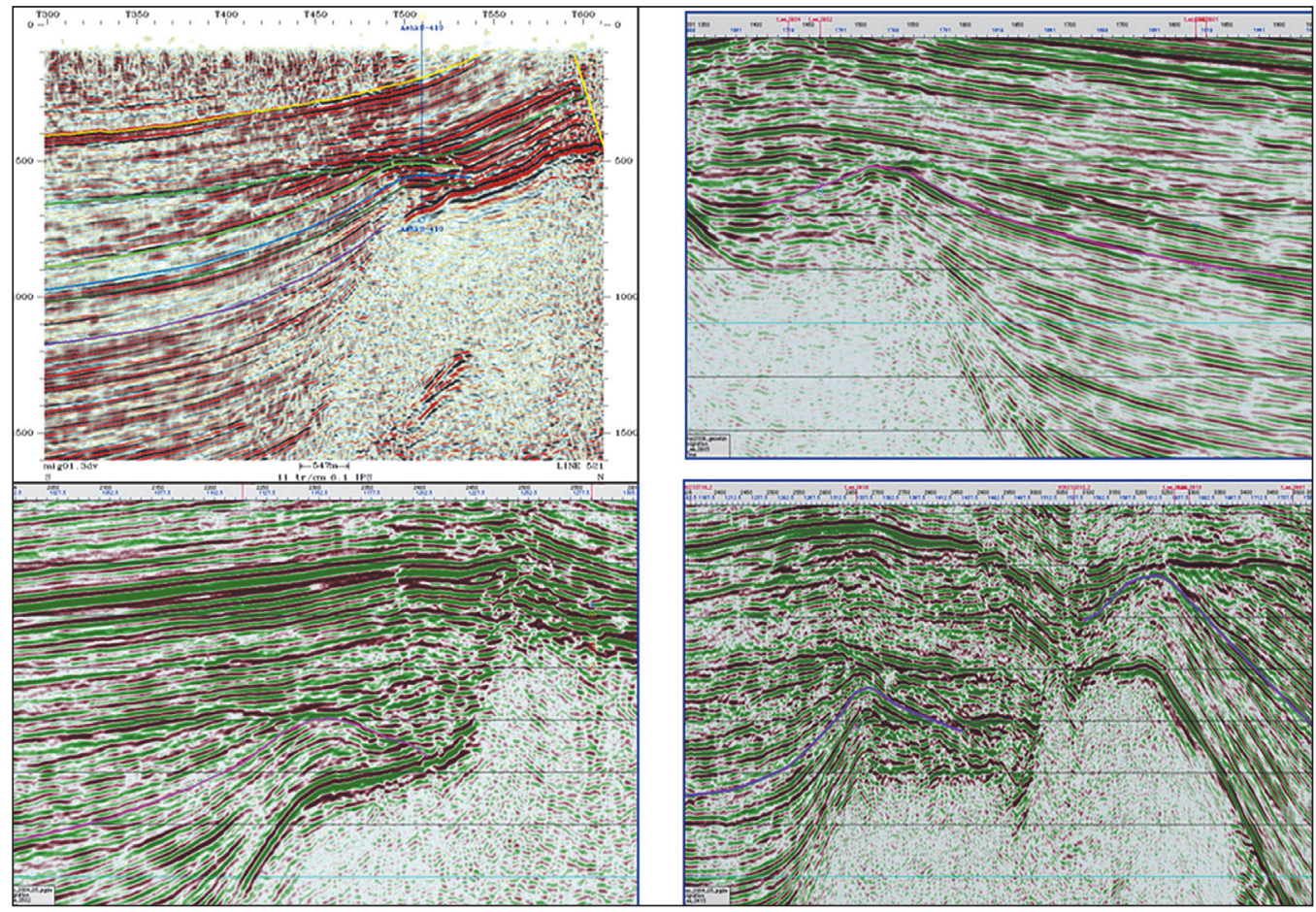

Рисунок 3 - Примеры структурно-седиментационных ловушек

соляной грядой) частью в направлении глубокопогруженных зон. Во внешних зонах этих ловушек обычно откладываются отложения нижнего триаса, которые продуктивны в мульдовых частях. Во внутренних зонах в отложениях среднего и верхнего триаса выявлены многопластовые газонефтяные залежи. Особо следует отметить роль соотношения соляных гряд и регионального наклона (погружения) надсолевого комплекса в межкупольных зонах в процессе латеральной миграции углеводородов;

- в пределах изучаемой территории сейсмическими исследованиями отмечено также наличие в подсолевых отложениях высокоамплитудных региональных разрывных нарушений;

- все эти факторы способствуют процессу вертикальной миграции углеводородов из подсолевых отложений, обладающих к тому же аномальным внутрипластовым давлением, превышающим в 1,5-1,8 раза нормальное гидростатическое давление, что немаловажно для осуществления возможной струйной миграции УВ в вышезалегающие надсолевые толщи.

Исходя из всестороннего анализа этих поисковых признаков, при выборе направления геологоразведочных работ на среднетриасовые отложения был сделан вывод, что перспективными зонами нефтегазонакопления в среднетриасовых отложениях в пределах исследуемой территории могут стать бессолевые мульды, расположенные в пределах зоны регионального выклинивания различных отделов триасовых отложений, протянувшейся полосой вдоль Астрахано-Актюбинской зоны поднятий по фундаменту. 


\section{ГЕОЛОГИЯ}

С учетом выявленных критериев была разработана и осуществлена активная программа геологоразведочных работ на территории Волго-Уральского междуречья и Эмбинского участка Прикаспийской впадины. Отработан большой объем сейсморазведочных профилей 2Д и были выбраны первоочередные участки, перспективные для бурения. На полученных обнаружениях впоследствии выполнены в большом объеме сейсморазведочные работы МОГТ зД.

В процессе исследований решались следующие задачи:

1) выделение сейсмостратиграфических комплексов в триасовом интервале осадочного чехла на основе интерпретации сейсмических временных разрезов;

2) увязка данных сейсморазведки и бурения;

3) выделение и изучение сейсмических фаций на основе объектно-ориентированной обработки и атрибутного анализа данных сейсморазведки;

4) прогноз зон, благоприятных для заложения поисковых скважин в триасовых отложениях.

Сейсмофациальный анализ, проведенный для каждого сейсмостратиграфического комплекса в межкупольных зонах, позволил выявить объекты, с которыми связаны основные перспективы поиска перспективных ловушек.

Новые подходы к объектно-ориентированной обработке и сейсмогеологический анализ с технологией прогнозирования и картирования структурно-седиментационных ловушек, примененные при проведении исследований, позволили в значительной степени уточнить геологическое строение и особенности формирования перспективных, в нефтегазоносном отношении, терригенно-карбонатных отложений триаса на большей части Прикаспийской впадины.

Проведенные работы привели к открытию ряда месторождений (Таскудук Западный, Ащиколь Южный, Бесшокы Южный, Сарлы, Каганай, Дулат, Шокат, Сарыкумак Западный и Сарыкумак Восточный, Жартобе, Карашказган, Орысказган Северный, Жантерек Северный, Мынтеке Южный, Биикжал), где продуктивны отложения триаса. В отложениях среднего триаса по данным ГИС и опробования установлено до десяти продуктивных горизонтов.

Результатом работ явилось также получение прогнозной карты распространения перспективных объектов в среднем триасе, аналогичных выявленным месторождениям (рисунок 4). Прогноз основывался на методе аналогий с учетом выявленных поисковых признаков.

Проведен всесторонний комплексный анализ материалов бурения и сейсморазведочных работ (структурные и литолого-фациальные карты, карты эффективных толщин и динамических атрибутов волнового поля) по солянокупольным структурам и межкупольным зонам, и в результате выработана достаточно обоснованная геологическая модель строения триасовых отложений.

Информация по технологии прогнозирования и картирования новых структурно-седиментационных ловушек была опубликована в научных журналах и сборниках [5], сделаны доклады на международных и республиканских геологических конференциях. Технология доступна и используется рядом компаний (ТОО «ФИОК лтд», АО РД «Казмунайгаз», «Кондор Петролеум», «Норд Каспиан Ойл Девелопмент» и др.) в практической деятельности для наращивания своих нефтегазовых ресурсов. 


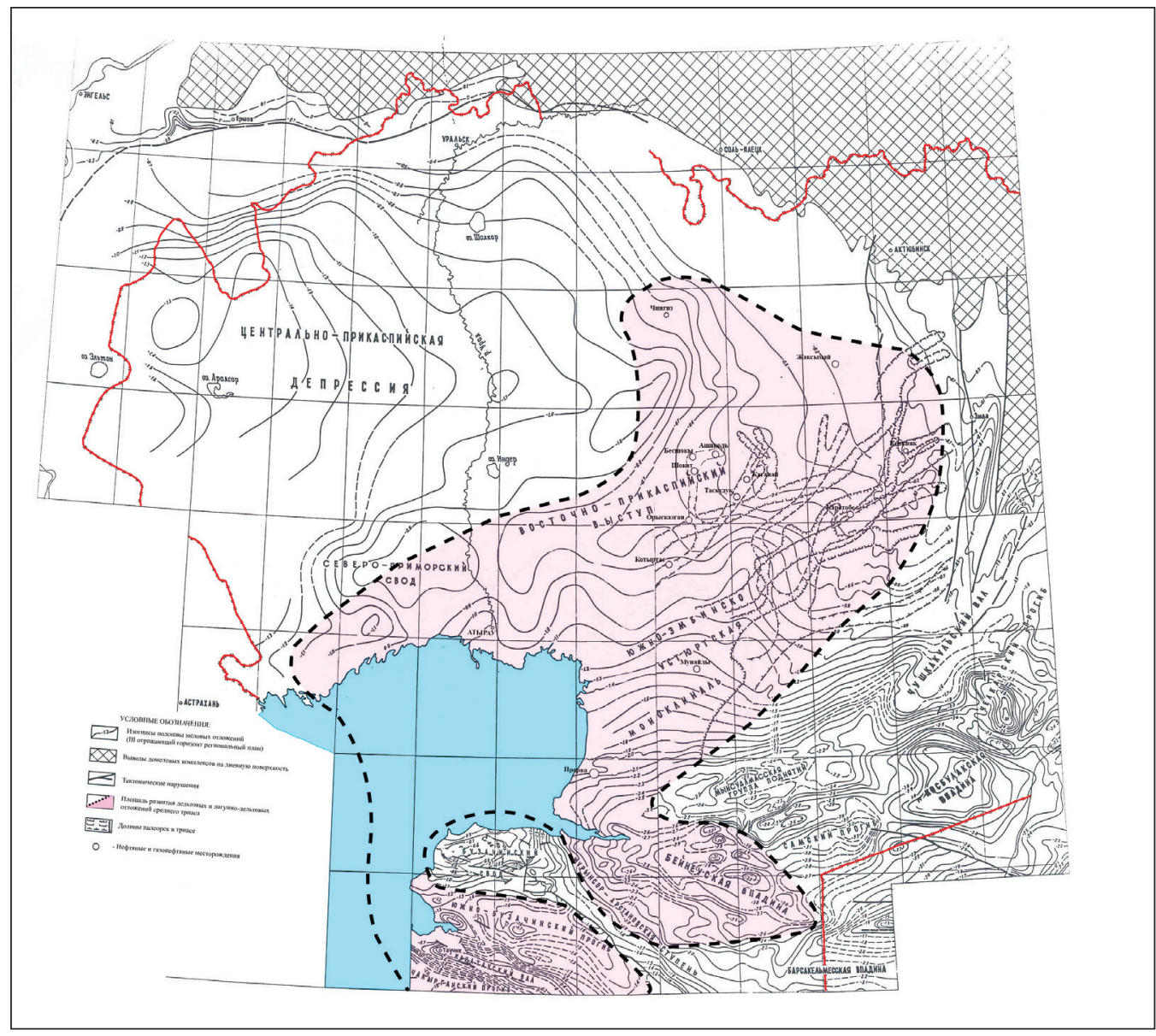

Рисунок 4 - Площадь развития перспективных отложений среднего триаса

Результаты не заставили себя долго ждать и последовали открытия на территориях, расположенных в южном, западном и юго-западном направлении от линии месторождений Бесшоки Южный - Дулат - Шокат - Копа. В качестве примеров можно привести открытия, сделанные другими компаниями в последние 5-6 лет: Боркылдакты, Сагиз Западный (Maxpetroleum), Дараймола Восточный (НорсКаспиан Ойл Девелопмент), Шоба (Кондор Петролеум), Новобогатинск Юго-Восточный, Уаз (АО РД КМГ) и др.

Практика показала эффективность разработанной объектно-ориентированной технологии обработки и сейсмогеологического анализа сейсмических данных, методика используется и вылилась в новое направление геологоразведочных работ на надсолевой комплекс отложений в Прикаспийской впадине, подтверждая правильность выбранной стратегии.

Доказано также, что структурно-седиментационные ловушки в среднем триасе распространяются практически по всей Прикаспийской впадине на территории развития активного процесса галокинеза и выдвигает надсолевые триасовые от- 
ложения, особенно в пределах Астраханско-Актюбинской системы дислокаций, в наиболее перспективные в нефтегазоносном отношении для поиска и открытия новых месторождений.

Применение технологии является приоритетной и на стадии доразведки уже открытых и разрабатываемых месторождений нефти и газа в юрско-меловых отложениях. Постановка детальных работ по данной методике на наиболее перспективных ловушках будет способствовать восполнению объемов прогнозных ресурсов и разведанных запасов промышленных категорий. Полученные данные позволяют не только по-новому пересмотреть перспективы надсолевого комплекса в целом, но и повысить успешность геологоразведочных работ, а также дать «второе дыхание» нефтегазоносным районам и старым промыслам Прикаспийской впадины.

\section{Таким образом, проведенные исследования позволяют сделать следующие выводы:}

1. Впервые выявлен новый тип ловушек нефти и газа в отложениях среднего триаса Прикаспийской впадины - структурно-седиментационный, позволивший определить и доказать перспективы нефтегазоносности триасовых отложений.

2. Разработана методика объектно-ориентированного сейсмогеологического анализа сейсмических данных для надежного выделения структурно-седиментационных ловушек и определены геолого-сейсмические критерии их прогноза.

3. Разработана и внедрена в производство технология по прогнозированию и картированию структурно-седиментационных ловушек нефти и газа в триасовых отложениях Прикаспийской впадины.

4. Данная методика объектно-ориентированного сейсмогеологического анализа сейсмических данных реализована на территории Прикаспийской впадины в пределах Актюбинской и Атырауской областей Республики Казахстан.

\section{ЛИТЕРАТУРА}

1 Грошев В.Г., Синельников А.В., Ескожа Б.А. и др. Эволюция межкупольной зоны Котыртас Северный-Мырзалы Восточный: новые возможности поиска углеводородов в верхнепермско-триасовых отложениях Прикаспийской впадины. // Геология нефти и газа. - 1993. - №8. - C. 10-15. [Groshev V.G., Sinelnikov A.V., Eskozha B.A. dr. Evolyuciya mezhkupol'noyj zony Kotyrtas Severnyj-Myrzaly Vostochnyj: novye vozmozhnocti poiska uglevodorodov v verkhnepermsko-triasovakh otlozheniyakh Prikaspyjskoj vpadiny // Geologiya nefti i gaza. - 1993. - №8. - S. 10-15]

2 Липатова В.В., Басилова С.К., Ескожа Б.А. и др. Стратиграфия среднетриасовых отложений междуречья Уил-Эмба. Депонирована в Известиях высших учебных заведений под №1014-МГ-91 от 19.06.1991 г. [Lipatova V.V., Basilova S.K., Eskozha B.A. Stratigrafiya srednetriasovykh otlozhenyj mezhdurech'ya Uil-Emba. Deponirovana v Izvestiyakh vysshikh uchebnykh zavedeniyakh pod No. 1014-MG-91 ot 19.06.1991

3 Ескожа Б.А., Воронов Г.В., Куантаев Н.Е. и др. Результаты и направления дальнейшей реализации нефтегазового потенциала надсолевых отложений юга Прикаспийской впадины // Известия НАН РК. - 2007. - №6. - С. 33-49. [Yeskozha B.A., Voronov G.V., Kuantayev N.E. i dr. Rezul'taty i napravleniya dal'neishej realizacii neftegazovogo potenciala nadsolevykh otlozhenij yuga Prikaspijskoj vpadiny // Izvestiya NAN RK. - 2007. - N. 6. - S. 33-49. 
4 Ескожа Б.А. Особенности строения и перспективы нефтегазоносности триасового комплекса юга Прикаспийской впадины // Известия НАН РК. Серия геологическая. 2008. - №4. - C.38-48. [Eskozha B.A. Osobennosti stroeniya neftegazonosnosti trasovogo kompleksa yuga Prikaspijskoj vpadiny // Izvestiya NANRK.Ser. Geol. - 2008. - 4. - S.3848.]

5 Воронов Г.В., Куантаев Н.Е., Ян Хуайи. Критерии выделения и опыт прогнозирования ловушек в триасовых отложениях юга Прикаспийской впадины // Труды ОНГК. - 2014. Вып. 4. -C. 226-232. [Voronov G.V., Kuantayev N.E., Yang Huai. Kriterii vydeleniya I opyt prognozirovaniya lovushek v triasovykh otlozheniyakh yuga Prikaspijskoj vpadiny/l Trudy ONGK. - 2014. - Vypusk.4. - S. 226-232]

6 Искужиев Б.А., Семенович В.В. Перспективы над солевого нефтеносного комплекса юго-востока Прикаспийского бассейна // Геология нефти и газа. -1992. - N.11.-C.6-9. [Iskuzhiev B.A., Semenovich V.V. Perspektivy nadsolevogo kompleksa uygo-vostoka Prikaspijskogo bassejna // Geologiya nefti i gaza. - 1992. - N. 11. -S. 6-9.

7 ИскужиевБ.А. Геологическоестроениеиперспективынефтегазоносноститриасовыхотложениймеждуречья Урала и Эмбы. Автореферат диссертации на соискание ученой степени к. г-м н. - Москва: ВНИГНИ, 1994. - 20 с. Искужиев Б.А. Геологическое строение и перспективы нефтегазоносности триасовых отложений междуречья Урала и Эмбы. Авторефрерат диссертации на соискание ученой степени к. г-м н. Москва: ВНИГНИ, 1994. - 20 с.[Iskuzhiev B.A. Geologicheskoe stroenie i perspektivy neftegazonosnosti triasovykh otlozhenij mezhdurech'ya Urelal Emby. Avtoreferat dissertacii na soiskanie uchenoi stepenik g-m n. - Moskva: VNIGNI, 1994. - 20 s.]

8 Barde J.P., Gralla P., Harwijanto J. and Marsky J. Exploration at the eastern erge of the Precaspian basin: Impact of data integration on Upper Permian and Triassic prospectivity //AAPG Bulletin.- 2002. - Vol. 86. - N.3 - P. 399-415.

9 Волож Ю.А., Воцалевский Э.С., Живодеров А.Б. и др. Проблемы нефтегазоносности надсолевых отложений Прикаспийской впадины // Известия АНКаз. ССР, Серия геологическая. - 1989. - №4. - С. 3-15. [Volozh Yu.A., Vocalevskij ES, Zhivoderov A.B. i dr. Problemy neftegazonosnosti nadsolevykh otlozhenij Prikaspijskoj vpadiny // Izvestiya, AN KazSSR, Ser. Geologicheskaya. - 1989. - N.4. - S.3-15.]

10 Volozh Yu.A., Talbot C.J., Ismail-Zadeh A.T. Salt structures and hydrocarbons in the Pricaspian basin // AAPG Bulletin. - 2003. - Vol. 87. -N2. - P. 313-334.

11 Проничева М.В., Саввинова Г.Н. Палеогеоморфологические предпосылки выявления нефтегазоносных зон в юрском и триасовом комплексах Северной Эмбы // Геология нефти и газа. - 1976. - №8. - C.21-27. [Pronicheva M.V., Savvinova G.N. Paleogeomorphologicheskie predposylki vyyavleniya neftegazonosnykh zon v yurskom i triasovom kompleksakh severnoj Emby // Geologiya nefti I gaza. - 1976. - N 8. - S. 21-27.]

12 Волож Ю.А., Дмитриевский А.Н., Леонов Ю.Г. и др. О стратегии очередного этапа нефтепоисковых работ в Прикаспийской нефтегазоносной провинции // Геология и геофизика. - 2009. - Т. 50. - №4. - C.341-362. [Volozh Yu.A., Dmitrievskij A.N., Leonov Yu.G. O strategii ocherednogo etapa neftepoiskovykh rabot v Prikaspijskoj neftegazonosnoj provincii // Geologiya i geophizika. - 2009. - T. 50. - N 4. - S. 341-362.]

13 Трохименко М.С. Структурно-седиментационный природный резервуар и ловушки в среднем триасе Прикаспийской впадины: закономерности расположения, механизм фрормирования, особенности образования залежей нефти и газа. Часть 1. // Нефть и газ. - 2012. - №2. - C. 81-95. [Trokhimenko M.S. Strukturno-sedimentacionnyj prirodnyj rezervuar I lovushki v srednem triase Prikaspijskoj vpadiny: zakonomernosti paspolozheniya, mekhanizm formirovaniya, osobennosti obrazovaniya zalezhi nefti i gaza. Chact' 1 // Neft' I gaz. - 2012. - N 2. - S. 81-95.] 


\section{ГЕОЛОГИЯ}

14 Трохименко М.С. Структурно-седиментационный природный резервуар и ловушки в среднем триасе Прикаспийской впадины: закономерности расположения, механизм формирования, особенности образования залежей нефти и газа. Часть 2. // Нефть и газ. - 2012. - №3. - C.15-29.[Trokhimenko M.S. Strukturno-sedimentacionnyj prirodnyj rezervuar I lovushki v srednem triase Prikaspijskoj vpadiny: zakonomernosti raspolozheniya, mekhanizm formirovaniya, osobennosti obrazovaniya zalezhi nefti I gaza. Chact' 2 // Neft' I gaz. - 2012. - N 3. - S. 15-29.]

15 Антипов М.П., Волож Ю.А. Особенности строения и нефтегазоносность надсолевого разреза Прикаспийской впадины // Нефть и газ. - 2012. - №1. - C.47-71. [Antipov M.P., Volozh Yu.A. Osobennosti stroeniya I neftegazonosnoct' nadsolevogo razreza Prikaspijskoj vpadiny // Neft' i gaz. - 2012. - N.1. - S.47-71.]

16 Обрядчиков О.С., Таскинбаев К.М., Мусагалиев М.З. и др. Особенности строения и нефтеносности триасовых отложений периферийных частей солянокупольных структур Прикаспийской впадины // Нефть и газ. - 2012. -№2. - C. 97-108. [Obryadchikov O.S., Taskinbaev K.M., Musagaliev M.Z. I dr. Osobennosti stroeniya I neftegazonosnocti triasovykh otlozhenij periferijnykh chastej solyanokupol'nykh struktur Prikaspijskoj vpadiny // Neft' i gaz. - 2012. - N 2. - S. 97-108.]

17 Sydykov K.Z., Matussevich A.V., Yeskozha B.A. Joint Use of Gravity, Seismic Data advances Precaspian salt modeling depth imaging // Oil \&Gas Journal. International Petroleum News and Technology. - 2000. - N 98(35). - P.28-35. 